\title{
NEW DATA ABOUT THE PRESENCE AND ABSENCE OF THE EXTERNAL FUNDAMENTAL SYSTEM IN ARCHOSAURS
}

\author{
Rafael César Lima Pedroso de Andrade ${ }^{1}$, Renan Alfredo Machado Bantim² ${ }^{2}$, Flaviana Jorge de Lima ${ }^{3}$, \\ Leomir dos Santos Campos ${ }^{4}$, Lúcia Helena de Souza Eleutério ${ }^{5}$, Juliana Manso Sayão ${ }^{6}$
}

\begin{abstract}
Resumo
A presença das lamelas circunferenciais externas (= external fundamental system - EFS) nos ossos dos tetrápodes, indica uma finalização efetiva de qualquer crescimento periosteal significante. Embora esteja presente em alguns Archosauromorpha, a ideia de um crescimento contínuo nesse grupo ainda permanece. Aqui são apresentados novos dados sobre presença de EFS em Neosuchia, um clado composto por crocodilomorfos terrestres, e suas implicações através da história evolutiva dos arcossauros. Utilizamos uma costela parcialmente completa, referida à um crocodilo dirossaurídeo $(\mathrm{CAV} 0014-\mathrm{V})$. O córtex era composto por tecido zonal-lamelar, rede vascular com ósteons primários e canais vasculares simples, dispostos longitudinalmente. Ósteons secundários ocorrem no córtex inferior e no tecido esponjoso, marcando o remodelamento ósseo. Periosticamente foi detectada a presença de EFS, indicando o final do crescimento assintótico do espécime e caracterizando-o como esqueleticamente maduro. Seu arranjo micro estrutural condiz com um animal de metabolismo e crescimento lentos, o que já é conhecido para táxons evolutivamente relacionados a Dyrosauridae. Até o momento foi registrado EFS em alguns Pseudosuchia, Crocodilomorpha, Pterosauria e Dinosauria, identificando o crescimento determinado em arcossauros desde os grupos extintos até táxons atuais. Novas evidências sobre EFS adicionariam suporte a hipótese de crescimento determinado como regra e não exceção nos Archosauria.
\end{abstract}

Palavras-chave: EFS. Crescimento determinado. Arcosauria. Paleohistologia.

\begin{abstract}
The presence of external fundamental system (EFS), in tetrapods, indicates an effective end in any significant periosteal growth. Although it is present in some Archosauromorpha, the idea of a continuous growth in this group remains. Here, new data about the presence of the EFS in Neosuchia, a clade composed of terrestrial crocodilomorphs, and its implications throughout arcosaurs evolutive history, are presented. We sampled a partially complete rib, referred to a dirosaurid crocodile (CAV 0014-V). The cortex was composed of a lamellar-zonal bone, vascularization constituted of primary osteons and simple vascular canals with longitudinal arrangement. Secondary osteons occurs in the inner cortex and spongy bone, indicating the remodeling process. The presence of EFS was detected periostically, revealing the end of assimptotic growth and characterizing the specimen as skeletically mature. Its microestructural arrangement is consistent with a slow growth and metabolical rate animal, which is already known to crocodiles and their basal related groups. Until now, the EFS has been detected in Pseudosuchia, Crocodilomorpha, Pterosauria and Dinosauria, identifying the determinate growth in archosaurs since extint to extant groups. New EFS evidences would support the hypothesis of determinate growth as a rule not an exception to Archosauria.
\end{abstract}

Keywords: External Fundamental System. Determinate Growth. Arcosauria. Paleohistology.

\footnotetext{
${ }^{1}$ Professor; Mestre; Programa de Pós-Graduação em Geociências, Centro de Tecnologia e Geociências, Universidade Federal de Pernambuco;

${ }^{2}$ Mestre; Programa de Pós-Graduação em Geociências, Centro de Tecnologia e Geociências, Universidade Federal de Pernambuco;

${ }^{3}$ Professora; Mestre; Programa de Pós-Graduação em Geociências, Centro de Tecnologia e Geociências, Universidade Federal de Pernambuco;

${ }^{4}$ Biólogo; Programa de Pós-Graduação em Geociências, Centro de Tecnologia e Geociências, Universidade Federal de Pernambuco;

${ }^{5}$ Bióloga; Laboratório de Biodiversidade do Nordeste, Universidade Federal de Pernambuco;

${ }^{6}$ Professora; Doutora; Laboratório de Biodiversidade do Nordeste, Universidade Federal de Pernambuco;

Autor correspondente: rafael-clpa1@ @otmail.com. Telefone: (81) 9796-0139.
} 


\section{Introduction}

The external fundamental system (EFS) is a form of bone microstructure deposits, sometimes present in the outermost cortex within a transverse bone cross-section, especially within long bones (WOODWARD; HORNER; FARLOW, 2011). This structure is sparsely vascularized and composed of slowly deposited parallel-fibered or lamellar tissue essentially producing a smooth, "finished" bone surface (e.g.,CORMACK, 1987; STARCK; CHINSAMY, 2002; PONTON et al., 2004). It can be found in long bones of animals when they reach their skeletal maturity. The presence of this layer indicates an effective cessation of growth in the periosteal circumference of long bones and confirms attainment of skeletal maturity (although it still can reach robustness) (LEE; O'CONNOR, 2013; WOODWARD; HORNER; FARLOW, 2011; ANDRADE; SAYÃO, 2014).

The EFS has already been reported in many reptile groups, but the idea that these animals could grow continuously throughout their lives, is still permanent. This microstructure has also been reported in mammals (CORMACK, 1987), birds (PONTON et al., 2004) and non-avian dinosaurs (ERICKSON et al., 2004; HORNER; PADIAN, 2004; PADIAN et al., 2004). In this work it is presented new data about the bone histology of a dyrosaurid from Paraíba Basin (Pernambuco, Brazil). It is allied to a revision, focused on the controversies and implications about the presence and absence of the EFS deposition and the interpretation of the growth throughout the evolutional history of the Archosaurs.

\section{Material and methods}

The specimen selected for sampling is a partially preserved rib (CAV 0014-V). This material is housed at the paleontological collection of the Centro Acadêmico de Vitória (Universidade Federal de Pernambuco), Vitória de Santo Antão, Pernambuco, Brazil. The rib was found at the type locality of Guarinisuchus munizi Barbosa, Kellner and Viana, 2008. CAV 0014- V was collected after the holotype, from the same horizon. It was found associated with an elongated mandible clearly belonging to a dyrosaurid and near to other isolated appendicular elements. This strongly suggests that the bone sampled here also belong to a dyrosaurid.

To prepare the histological slide, a $0.5 \mathrm{~cm}$ sample was obtained from the mid portion of the rib (Fig. $1 \mathrm{~B}$ ). The bones were subsequently measured and photographed according to the protocol proposed by Lamm (2013). The samples were embedded in epoxy clear resin RESAPOL T-208 catalysed with 
BUTANOX M50 and cut with a diamond-tipped blade on a saw (multiple brands). Next, the mountingside of the sections were wet-ground using a metallographic polishing machine (AROPOL-E, Arotec LTDA) with Arotec abrasive papers of increasing grit size (60/P60, 120/P120, 320/P400, 1200/P2500) until a final thickness of 30-60 microns was reached. To observe the histological structures, an optical microscope in transmitted light mode with parallel/crossed nicols and fluorescence filters were used to enhance birefringence. Representative histological images were taken using an AxioCam digital sight camera (Zeiss Inc., Barcelona, Spain) mounted to an Axio Imager.M2 transmitted light microscope (Zeiss Inc. Barcelona, Spain).

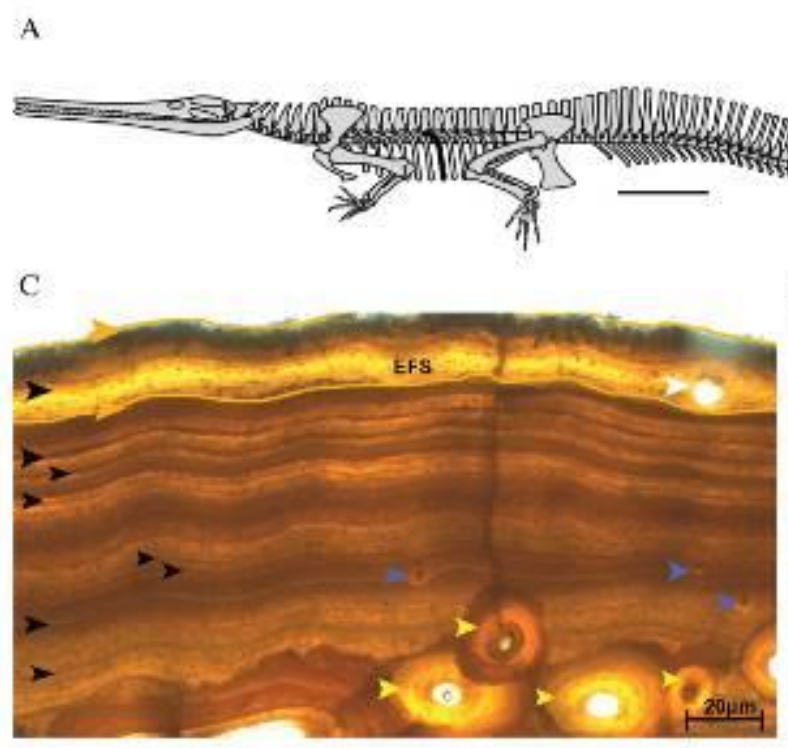

B

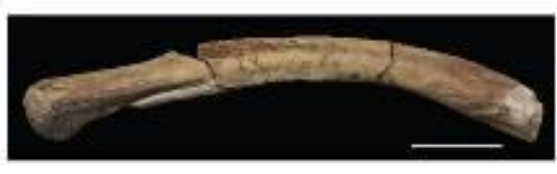

D

Figure 1. A) Scketch of a Dyrosaurid skeleton with the corresponding rib marked in black (Scale bar $=10 \mathrm{~cm})$. B) General view of the sampled rib CAV 0014-V (Scale bar $=10 \mathrm{~cm}$ ). C) Cortical view of the rib. Blue arrows indicates the vascular canals, yellow arrows point to secondary osteons, white arrows to the primary osteons and black arrows point to the LAGs. The Orange line delimitate the external fundamental system (EFS). D) The remodeled area with yellow arrow indicating the secondary osteons.

\section{Results}

The rib (CAV 0014-V) was, practically, complete. The section was performed as close as possible from the middle of the bone, where the information about the microestructures is more complete. The cortex is composed of lamellar-zonal bone, with $105.42 \mu \mathrm{m}$ of thickness. The osteocyte density is high throughout the cortex, they are located around the vascular canals. The density of these canals changes, substantially, in the tissue, which shows a low vascularization in the outer portion, increasing towards to the center and inner portion. The vascularization consists of simple primary osteons and vascular canals. The orientation of the vascular canals is predominantly longitudinal, showing signals of anastomosis. In 
this area the beginning of the remodeling process is visible. The rib presents three lines of arrested growth (LAGs) in the outer cortex, followed by a double-LAG. The fourth and fifth lines are located more under, towards the spongy bone. It is not possible to assume the real age of this specimen, due to the presence of secondary osteons in the cortex. These evidences of remodeling process can obscure the real number of LAGs. Little secondary osteons are observed in the cortex and some, rarer, in the EFS, showing the remodeling in this area. They are higher in number and size, and increase towards the spongious tissue, at the mid and inner portion. In this latter area, there are many erosion lacunae and the secondary osteons show some anastomosis, reaching big sizes.

\section{External Fundamental System in Archosaurs}

CAV 0014-V showed a clear deposition of the External Fundamental System (= EFS). In this structure was identified a single line of arrested growth, what means that even after it reached its final size (in length), this animal still had a moment of growth arrest. In Archosaurs, the EFS has been identified in some groups (Fig. 2). In Pseudosuchia, this microestructure was reported in the femur of Stagonolepis (DE RICQLÈS et al., 2003), in the humerus of Postosuchus kirkpatricki Chatterjee, 1985 and in Terrestrisuchus (DE RICQLÈS et al., 2003). In Mesoeucrocodylia, it is present in the femur of an extant and captive Alligator mississipiensis Woodward, Horner and Farlow, 2011a member of the Eusuchia. In the crocodile fossil record, this structure was described in the femur of a dyrosaurid, which composes the Neosuchia clade. In the Pterosauria the EFS is reported in an ornithocheirid ulna (STEEL, 2008), in a front limb of the small azhdarchid Montanazhdarcho (PADIAN; DE RICQLÈS; HORNER, 1995). Also it is present in some bones of large pterodactyloids (DE RICQLÈS et al., 2000; SAYÃO, 2003; STEEL, 2008) and in a wing phalanx of Tropeognathus cf. T. mesembrinus (KELLNER et al., 2013). In the Dinosauria the EFS has been reported in many taxa like in a basal sauropodomorph, in Stegosaurus dorsal plates (SAITTA, 2015), in the tibia of an hadrosaurian dinosaur Hypacrosaurus stebingeri Horner and Currie, 1994 (HORNER; DE RICQLÈS; PADIAN, 1999).

The Deinonychus antirrhopus Ostrom, 1969 specimen has revealed an EFS within the gastralia and dorsal ribs (PARSONS; PARSONS, 2015). The EFS has also been detected in the fibula of a Tyrannosaurus (HORNER; PADIAN, 2004). In avian dinosaurs most of the records belongs to neognathous birds (AMPRINO; GODINA, 1947). In those, to date, it is well developed in the ratites including Struthio, Rhea, and Casuarius (CHINSAMY; CHIAPPE; DODSON, 1995). Moreover this structures is well developed in the basal bird Confuciusornis (DE RICQLÈS et al., 2003). 

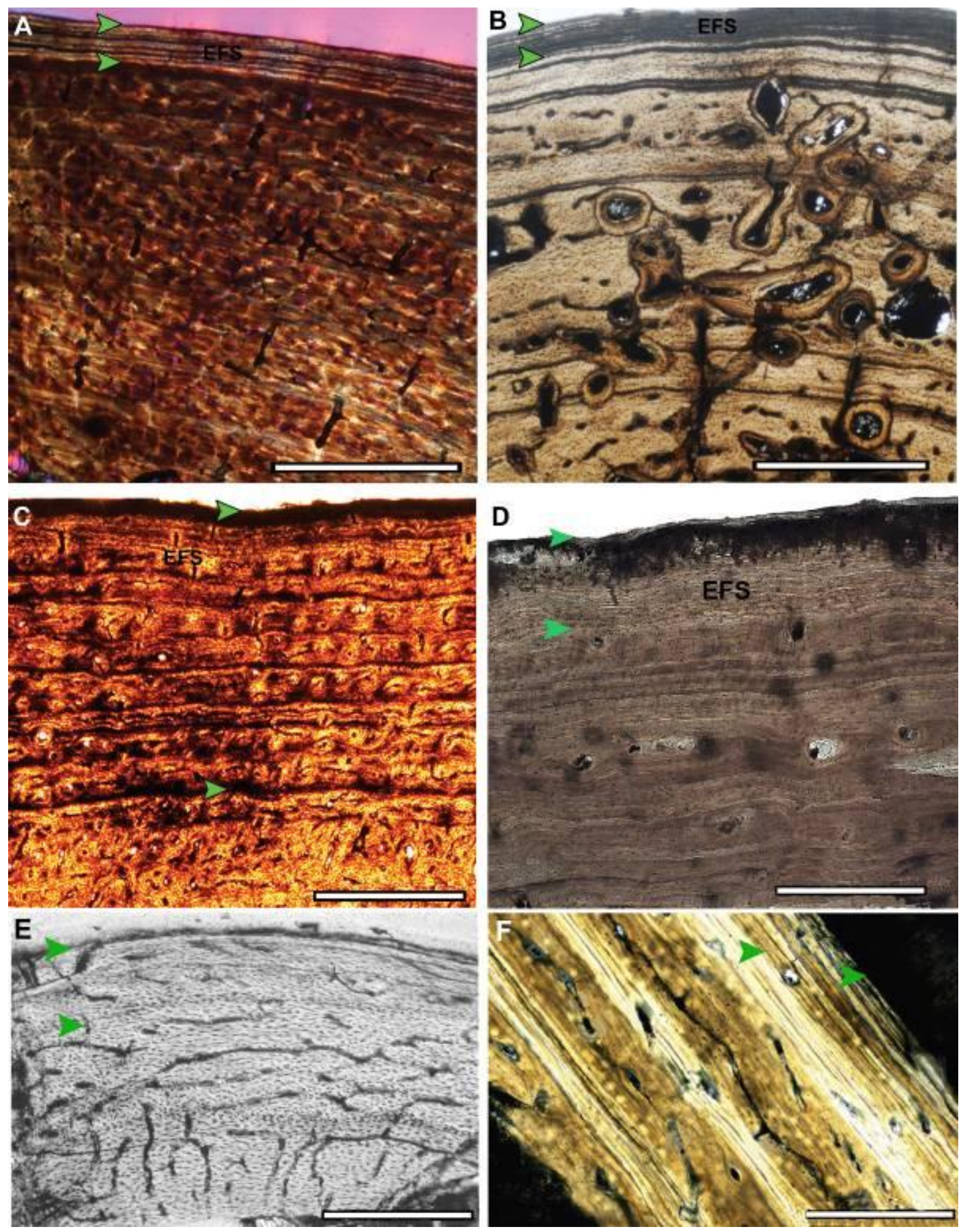

Figure 2. A) Femur photomicrograph of a captive Alligator mississippiensis (Scale bar = $2 \mathrm{~mm}$.). B) bone histology of the the humeral diaphysis of a Desmatosuchus (Scale bar $=1 \mathrm{~mm}$ ). C) Outer diaphyseal cortex from the fibula of a Tyrannosaurus (Scale bar $=1 \mathrm{~mm}$ ), modified from Woodward; Horner and Farlow (2011). D) Femoral cross-section of a Dyrosaurid crocodile (Scale bar = $1 \mathrm{~mm}$ ). E) Bone histology of the femoral diaphysis of Confuciosornis sanctus after Hou et al., 1995 (Scale bar = $1 \mathrm{~mm}$ ), modified from De Ricqlès et al., (2003). F) Outer diaphyseal cortex from the first wing phalanx of a 
Tropeognathus cf. T. mesembrinus (Scale bar $=1 \mathrm{~mm}$ ), modified from Kellner et al., (2013). The green arrows marks the EFS in all the micrographies.

\section{Discussion}

In archosaurs the history of determined growth is present since the basal groups, until the recent ones (Fig. 3) (DE RICQLÈS et al., 2003; WOODWARD; HORNER; FARLOW, 2011). This idea has already been aim of discussions, but the end of linear growth, which makes the animal increase its total length, is remarked with the deposition of the external fundamental system (CORMACK, 1987; CHINSAMY, 1990; HORNER et al., 1999; DE RICQLÈS et al., 2003; ERICKSON et al., 2004; SANDER et al., 2006; XU et al., 2006; KÖHLER; MOYÀ-SOLÀ, 2009; WOODWARD; HORNER; FARLOW, 2011). It indicates the beginning of the secondary growth, which provides thickness due to the constant external layering. To be considered an EFS, the structure must present one or uncountable LAGs (when they are closely spaced) indicating a continuous accretion of the annuli that are deposited circannually, depending on the physiology of the animal and/or the external pressures it had been through (CASTANET et al., 1977; DE BUFFRÉNIL, 1980; HUTTON, 1986; ANDRADE; SAYÃO, 2014). The presence of the EFS in crocodilians is rare, despite being found in thirty femurs of captive Alligator mississippiensis (WOODWARD; HORNER; FARLOW, 2011), it is not broadly found in many taxa. This is not the first time this microstructure occurs in Dyrosauridae (ANDRADE; SAYÃO, 2014). The latter authors have reported this element in the femur of a dyrosaurid crocodilian, and the new data brought up by this work enforces the determinate growth within this clade.

The description of the tissue pattern of the rib is consistent to the femur and tibia, characterizing this specimen by having a low growth rate (ANDRADE; SAYÃO, 2014). This lamellar-zonal bone is also consistent to the pseudosuchian taxa previously sampled (DE RICQLÈS; PADIAN; HORNER, 2003), to another group of marine crocodiles, the Thalattosuchia (HUA; DE BUFFRÈNIL, 1996) and to descriptions of other skeletal elements of Dyrosaurus phospaticus (BUFFETAUT et al., 1982). In fact, EFS in derived Neosuchians should be expected, because determinate growth histories are found in some extinct pseudosuchians and repeatedly established for dinosaurs and pterosaurs. The confirmation of determinate growth of A. mississippiensis (WOODWARD; HORNER; FARLOW, 2011) enforces that this is a basal characteristic of Archosauria. 


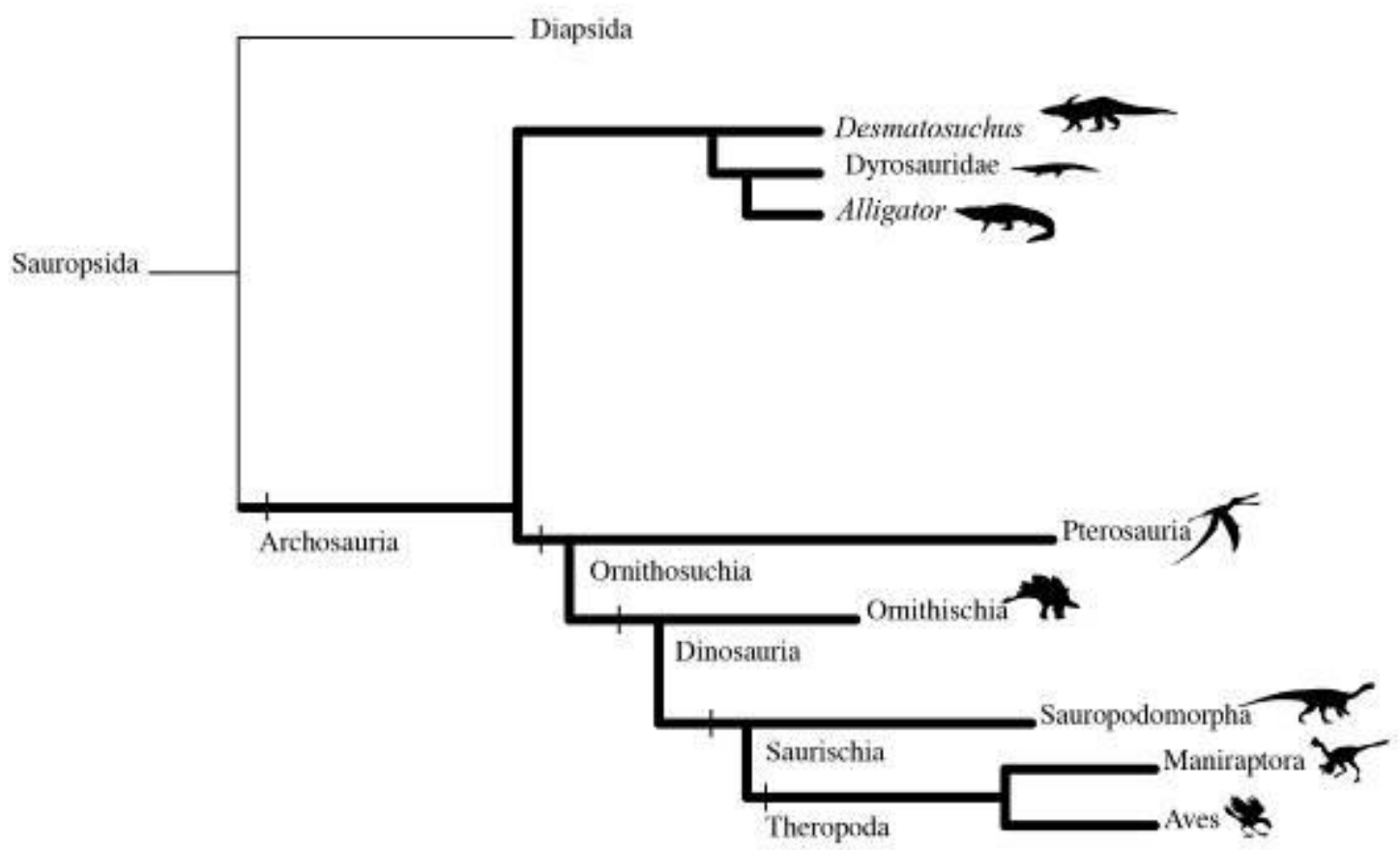

Figure 3. Generalized cladogram of Archosauria (redrawn from Woodward; Horner and Farlow, 2011) diagramming the presence of an EFS in various groups. The black branches mean that the EFS has been identified in these groups.

The bone deposition patterns within basal pseudosuchia, advanced Neosuchia and extant Eusuchia present some general similarities in the sequence of deposition. In the long bones of all these taxa, it appears to occur an early period of relatively rapid growth (common to vertebrates in general). After this initial stage, the bone growth generally seems to settle into a typical pattern of lamellar-zonal cycles. In each cycle, a burst of moderately well-vascularized bone, in which most osteons are longitudinally oriented, is followed by a layer of avascular bone, and capped by a LAG (DE RICQLÈS et al., 2003; WOODWARD; HORNER; FARLOW,2011; ANDRADE; SAYÃO, 2014). This is the contrast to the condition of dinosaurs and pterosaurs (PADIAN; HORNER; DE RICQLÈS, 2004). Young pterosaurs grew rapidly, but growth rates slowed when sub-adult size was reached, where upon an endosteal lamella formed on the surface and an EFS formed on the periosteal surface. It indicates that growth has also ceased or slowed to a negligible rate (STEEL, 2008). This condition observed in pterosaurs, are not the same found in Pseudosuchia and in advanced and extant crocodilians lineage, including CAV 0014-V. The specimen sampled, showed a cortex composed of LZB pattern, a simple arrangement of the vascular canals, appearance of cyclical LAGs and the deposition of the EFS. All these characteristics are indicative of a slow growth and skeletally mature individual. It also corroborates to the idea that archosaurs have a determinate growth. 
In dinosaurs, it was reported fast-growing tissue along the walls of the medullary cavity (DACKE et al., 1993). However, Schweitzer et al. (2005) first discovered fossilized tissue corresponding to medullary bone along the medullary cavity of the limb bones of Tyrannosaurus rex Osborn, 1905. Subsequently others as Lee and Werning (2008) also found it in Allosaurus (another theropod) and Tenontosaurus (an ornithopod), establishing its presence not only in theropods (which include birds), but also in both major lineages of dinosaurs, the Saurischia and Ornithischia. Dinosaurs and pterosaurs that reach large size show the same predominance of fibro-lamellar tissue that is also seen in larger birds and mammals today (e.g., DE RICQLÈS et al., 2000; HORNER; DE RICQLÈS; PADIAN, 2000). It was also present in woven bone, characterized by animals with high metabolical growth rates (CURRY, 1999; DE RICQLÈS et al., 2003). Nevertheless, opposite to crocodilians, leading to the hypothesis that even belonging to archosaur group, the crocodilians went through a different growth and metabolically pathway.

Hence, one hypothesis could postulate that the patterns seen in pseudosuchians and ornithosuchians originated at the bases of these stem-groups and have persisted to the present. Pseudosuchians, Neosuchians and Eusuchians have always been characterized by relatively slow and cyclical growth patterns; ornithosuchians have always been characterized by relatively rapid growth patterns that only diminish in rate as adult size is reached (BUFFETAUT et al., 1982; HUA; DE BUFFRÈNIL, 1996; DE RICQLÈS; PADIAN; HORNER, 2003). It indicates two different growth strategies within archosauria.

\section{Conclusion}

The absence of EFS in some archosaur groups does not imply in its real absence. It could be provenient of the ontogenetic stage of the samples or because of the preservation of the outer cortex. Besides, the scarcity of paleohistological works within some taxa, also contributes to it. The discovery of an EFS layer in other group of reptiles, could give the support to the hypothesis of the determined growth as a rule, and not an exception in the archosaurs.

It also cannot be assumed that pseudosuchians display the basal archosaurian pattern. An alternate hypothesis, therefore, could be that these histological patterns, and the modes of growth that they represent, evolved in archosauriforms and were carried on (and elaborated) in ornithosuchians and pseudosuchians secondarily reverted to a less well vascularized matrix, and a less determinate, more 
cyclical pattern of growth that persists in crocodiles today (DE RICQLÈS, 1978a; SCHWEITZER; MARSHALL, 2001; DE RICQLÈS et al., 2003).

\section{Acknowledgments}

We thank Dr. Antônio Barbosa (DEGEO-UFPE) for collecting the material used here, Matheus Barbosa for helping with figures edition. We would like to thank CNPq (Conselho Nacional de Desenvolvimento Científico e Tecnológico) for the funding support. We thank PPGEOC-UFPE (Programa de Pós-Graduação em Geociências da Universidade Federal de Pernambuco).

\section{References}

AMPRINO, R.; GODINA, G. La struttura delle ossa nei vertebrati.Ricerche comparative negli anfibi e negli amnioti. Commentationes. Pontificia Academia Scientarum, v. 11, p. 329-467, 1947.

ANDRADE, R.C.L.P.; SAYÃO, J.M. Paleohistology and Lifestyle Inferences of a Dyrosaurid (Archosauria: Crocodylomorpha) from Paraíba Basin (Northeastern Brazil). PLoS ONE, v. 9, n. 7, 2014.

BARBOSA, J.A.; KELLNER, A.W.A.; VIANA, M.S.S. New dyrosaurid crocodylomorph and evidences for faunal turnover at the K-P transition in Brazil. Proceedings of the Royal Society B, v. 275, p. 13851391, 2008.

BUFFETAUT, E.; DE BUFFRÉNIL, V.; DE RICQLÈS, A.J.; SPINAR, Z.V. Remarques anatomiques et paléohistologiques sur Dyrosaurus phosphaticus, crocodilien mesosuchien des Phosphates yprésiens de Tunisie. Annales de Paleontologie, v. 68, p. 327-341, 1982.

CASTANET, J.; MEUNIER, A.; DE RICQLÈS, A.J.L'enregistrement de la croissance cyclique par les tissue osseux chez les vertébrés poikilothermes: donnés comparative et essai de synthese. Bulletin scientifique de la France et de la Belgique, v. 3, p. 183-202, 1977.

CHINSAMY, A. Physiological implications of the bone histology of Syntarsus rhodesiensis (Saurischia: Theropoda). Palaeontologia africana, v. 27, p. 77-82, 1990.

CHINSAMY, A.; CHIAPPE L.M.; DODSON, P. Mesozoic avian bone microstructure: physiological implications. Paleobiology, v. 21, p. 561-574, 1995.

CORMACK, D.H. 1987. Ham’s Histology. JB Lippincott Company, Philadelphia, 1987.

CURRY, K.A. Ontogenetic histology of Apatosaurus (Dinosauria, Sauropoda): new on growth rates and longevity. Journal of Vertebrate Paleontology, v. 19, p. 654-665, 1999. 
DACKE, C.G.; ARKLE, S.; COOK, D.J.; WORMSTONE, I. .; JONES, S.; ZAIDI, M.; BASCAL, Z.A. Medullary bone and avian calcium regulation. Journal of Experimental Biology, v. 184, p. 63-88, 1993.

DE BUFFRÉNIL, V. Mise em évidence de l'incidence dês conditions de milliu sur La croissance de Crocodylus siamensis (Schneider 1801) et valeurdes marques de croissance squelettiques pour l'evaluation de l'âge individuel. Archives de zoologie expérimentale et générale, v. 121, p. 63-76, 1980.

DE RICQLÈS, A. J. Recherches paléohistologiques sur les os longs des tétrapodes VII. Sur la classification, la signification fonctionnelle et l'histoire des tissus osseux des tetrápodes. Ttroisième partie, évolution. Annales de Paléontologie, v. 64, n. 1, p. 85-111, 1978.

DE RICQLÈS, A.J.; PADIAN, K.; HORNER, J.R. On the bone histology of some Triassic pseudosuchian archosaurs and related taxa. Annales de Paleontologie, v. 89, p. 67-101, 2003.

DE RICQLÈS, A.J.; PADIAN, K.; HORNER, J.R.; FRANCILLON-VIEILLOT, H. Palaeohistology of the bones of pterosaurs (Reptilia: Archosauria): anatomy, ontogeny, and biomechanical implications. Zoological Journal of the Linnean Society, v. 129, p. 349-385, 2000.

DE RICQLÈS, A.J.; PADIAN, K.; HORNER, J.R.; LAMM, E.-T.; MYHRVOLD, N. Osteohistology of Confuciusornis sanctus (Theropoda: Aves). Journal of Vertebrate Paleontology, v. 23, n. 2, p. 373-386, 2003.

ERICKSON, G.M.; MAKOVICKY, P.J.; CURRIE, P.J.; NORELL, M.A.; YERBY, S.A.; BROCHU, C.A. Gigantism and comparative life-history parameters of tyrannosaurid dinosaurs. Nature, v. 430, p. 772-775, 2004.

HORNER, J.R.; DE RICQLÈS, A.J.; PADIAN, K. Variation in Dinosaur Skeletochronology Indicators: Implications for Age Assessment and Physiology. Paleobiology, v. 25, n. 3, p. 295-304, 1999.

HORNER, J.R.; DE RICQLÈS, A.J.; PADIAN, K. Long bone histology of the hadrosaurid dinosaur Maiasaura peeblesorum: growth dynamics and physiology based on an ontogenetic series of skeletal elements. Journal of Vertebrate Paleontology, v. 20, p. 115-129, 2000.

HORNER, J.R.; PADIAN, K. Age and growth dynamics of Tyrannosaurus rex. Proceedings of the Royal Society of London, Series B, v. 271, p. 1875-1880, 2004.

HUA, S.; DE BUFFRÉNIL, V. Bone histology as a clue in the interpretation of functional adaptations in the Thalattosuchia (Reptilia, Crocodylia). Journal of Vertebrate Paleontology, v. 16, p. 703-717, 1996.

HUTTON, J.M. Age determination of living Nile crocodiles from the cortical stratification of bone. Copeia, v. 1986, p. 332-341, 1986.

KELLNER, A.W.A.; CAMPOS, D.A.; SAYÃO, J.M.S.; SARAIVA, A.A.F.; RODRIGUES T.; OLIVEIRA, G.; CRUZ, L.A.; COSTA, F.R.; SILVA, H.P.; FERREIRA, J.S. The largest flying reptile from Gondwana: a new specimen of Tropeognathus cf. T. mesembrinus Wellnhofer, 1987 (Pterodactyloidea, Anhangueridae) and other large pterosaurs from the Romualdo Formation, Lower Cretaceous, Brazil. Anais da Academia Brasileira de Ciências, v. 85, n. 1, p. 113-135, 2013.

KÖHLER, M.; MOYÀ-SOLÀ, S. Physiological and life history strategies of a fossil large mammal in a resource-limited environment. Proceedings of the National Academy of Sciences of the United States of America, v. 106, n. 48, p. 20354-20358, 2009. 
LAMM, E.T. Bone Histology of Fossil Tetrapods. In: PADIAN K, LAMM E-T. Preparation and Sectioning of Specimens. University of California Press, 2013, p. 55160.

LEE, A.H.; O'CONNOR, P.M. Bone histology confirms determinate growth and small body size in the noasaurid theropod Masiakasaurus knopfleri. Journal of Vertebrate Paleontology, v. 33, n. 4, p. 865876, 2013.

LEE, A.H.; WERNING, S. Sexual maturity in growing dinosaurs does not fit reptilian growth models. Proceedings of the National Academy of Sciences USA, v. 105, p. 582-587, 2008.

PADIAN, K.; DE RICQLÈS, A.J.; HORNER, J.R. Bone histology determines identification of a new fossil taxon of pterosaur (Reptilia: Archosauria). Comptes Rendus de l'Académie des Sciences, Serie IIa, v. 320, p. 77-84, 1995.

PADIAN, K.; HORNER, J.R.; DE RICQLÈS, A.J. Growth in small dinosaurs and pterosaurs: the evolution of archosaurian growth strategies. Journal of Vertebrate Paleontology, v. 24, p. 555-571, 2004.

PARSONS, W.L.; PARSONS, K.M. Morphological Variations within the Ontogeny of Deinonychus antirrhopus (Theropoda, Dromaeosauridae). PLoS ONE, v. 10, n. 4, 2015.

PONTON, F.; ELZANOWSKI, A.; CASTANET, J.; CHINSAMY, A.; DE MARGERIE, E.; DE RICQLÈS, A.J.; CUBO, J. Variation of the outer circumferential layer in the limb bones of birds. Acta Ornithologica, v. 39, p. 21-24, 2004.

SAITTA, E.T. Evidence for Sexual Dimorphism in the Plated Dinosaur Stegosaurusmjosi (Ornithischia, Stegosauria) from the Morrison Formation (Upper Jurassic) of Western USA. PLoS ONE, v. 10, n. 4, 2015.

SAYÃO, J.M. Histovariability in bones of two pterodactyloidpterosaurs from the Santana Formation, Araripe Basin, Brazil:preliminary results. In: BUFFETAUT, E.; MAZIN, J.-M. Evolution and Palaeobiology of Pterosaurs. Geological Society of London, Special Publication, 2003. v. 217, p. 335342.

SCHWEITZER, M.H.; MARSHALL, C.L. A molecular model for the evolution of endothermy in the dinosaur-bird lineage. Journal of Experimental Zoology (Molecular Development and Evolution), v. 291, p. 317-338, 2001.

SCHWEITZER, M.H.; WITTMEYER, J.L.; HORNER, J.R. Gender-specific reproductive tissue in ratites and Tyrannosaurus rex. Science, v. 308, p. 1456-1460, 2005.

STARCK, J.M.; CHINSAMY, A. Bone microstructure and developmental plasticity in birds and other dinosaurs. Journal of Morphology, v. 254, p. 2002.

STEEL, L. 2008. The palaeohistology of pterosaur bone: an overview. Zitteliana, v. B28, p. 109-125, 2008.

XU, X.; CLARK, J. M.; FORSTER, C.A.; NORELL, M.A.; ERICKSON, G.M.; EBERTH, D.A.; JIA, C.K.; ZHAO, Q. A basal tyrannosauroid dinosaur from the Late Jurassic of China. Nature, v. 439, p. 715-718, 2006.

WERNING, S. The Ontogenetic Osteohistology of Tenontosaurus tilletti. PLoS ONE, v. 7, n. 3, 2012. 
WOODWARD, H.N.; HORNER, J.R.; FARLOW, J.O. Osteohistological evidence for determinate growth in the American Alligator. Journal of Herpetology, v. 45, n. 3, p. 339-342, 2011.

Recebido: $13 / 05 / 2015$

Aceito: $14 / 07 / 2015$ 